\title{
The Problem of Defence Intelligence
}

Professor Philip H.J. Davies ${ }^{1}$

Director, Brunel Centre for Intelligence and Security Studies

Brunel University

Uxbridge, Middlesex

UK UB8 3PH

Email:phililp.davies@brunel.ac.uk

Tel: +44 (0)1895266 827

${ }^{1}$ Philip.davies@brunel.ac.uk 


\section{Abstract}

The following article argues that defence intelligence in general, and Britain's Defence Intelligence organization in particular, represents an area in intelligence studies that is significantly underinvestigated. It makes the case that the significance of understanding defence intelligence and DI lies not only in a general lack of illumination but because DI is subject to and prompts a range of difficulties and challenges that are either especially acute in the defence context or have ramifications for the wider intelligence community that remain to be fully appreciated. Particular attention is given to DI's remit being divided between Ministry of Defence and national requirements, problems of fixed-sum resourcing an intelligence function with national responsibilities that is subordinate to Departmental spending structures and priorities, fraught positioning of defence intelligence in Departmental line management and finally a chronic lack of public or official interest or scrutiny. The article concludes that the UK's experience has echoes elsewhere, notably in the United States, and that wider international study of defence intelligence is both long overdue and may have implications for understanding of national and wider intelligence institutions and processes.

\section{The Neglected Handmaiden}

It is only slightly more than thirty years since the field of academic intelligence studies began to take a distinct disciplinary form with the nearly simultaneous appearance of its two principle nonclassified periodicals. ${ }^{2}$ In that period the volume, coverage, sophistication and impact of scholarship in the field have expanded quite literally by orders of magnitude. And yet isolated lacunae and thinly covered shoals and sandbanks remain as often as near its heart as its fringes. One such body of shallows is the evolution, role and significance of defence intelligence. The notion of military intelligence is, of course, a well-established one and the emergence of armed service intelligence functions is an accepted and highly conventional aspect of the highly developed national intelligence evolutionary narrative. ${ }^{3}$ Indeed, much of the early work on intelligence dealt with intelligence and war variously at the tactical, theatre or operational and grand strategic levels. ${ }^{4}$ And so it is more than a little surprising that very little attention has been paid to defence intelligence. In the UK there is no official history of defence intelligence to match those of two of the three national agencies and the Joint Intelligence Organisation in the Cabinet Office ${ }^{5}$ or 'officially indulged' ${ }^{6}$

\footnotetext{
${ }^{2}$ Appearing c.1984, both Intelligence and National Security and the International Journal of Intelligence and Counterlntelligence are, of course, considerably predated by the originally classified US intelligence community journal Studies in Intelligence.

${ }^{3}$ This narrative is typified by Christopher Andrew's seminal Secret Service: the Making of the British Intelligence Community (London: Sceptre, 1986)

${ }^{4}$ For example, the ground-breaking British official history, H. Hinsley et al British Intelligence in the Second World War 5 vols (London: HMSO, 1979, 1981, 1984, 1983, 1990) concentrated on theatre- or campaign-level intelligence and coordination at the national strategy level but avoided detailed engagement with intelligence. ${ }^{5}$ Christopher Andrew. The Defence of the Realm: The Authorized History of MI5. (London: Penguin,2010), Keith Jeffery. MI6: The History of the Secret Intelligence Service 1909-1949 (London: Bloomsbury, 2011); Michael Goodman The Official History of the Joint Intelligence Committee: Volume I: From the Approach of the Second World War to the Suez Crisis (London: Routlege, 2015).

${ }^{6}$ The author's own review description of Richard J. Aldrich GCHQ: The Uncensored Story of Britain's Most Secret Intelligence Agency (London: HarperPress, 2010), see Philip H.J. Davies 'Step Changes and Learning Curves in the History of British Intelligence' Contemporary European History Vol.22 No.4 pp.687, 694, reviewing
} 
independent academic history. Despite achieving its fiftieth year in 2015 there has not even been a vaguely hagiographic and less vaguely self-congratulatory moment of celebration comparable to Charles Scanlon's In Defence of the Nation: DIA at Forty Years. ${ }^{7}$ To be sure, Huw Dylan (also contributing to this issue) has provided an excellent account of DI's lineal precursor, the Joint Intelligence Bureau ${ }^{8}$ and I have examined DI's evolving position within the wider machinery of British national intelligence and in contrast with its US counterparts' status and role. ${ }^{9}$ Beyond a (rather understandably) disgruntled post-Iraq memoire by one of its senior analysts ${ }^{10}$ there are no monographs on UK Defence Intelligence after the 1964 Mountbatten Reforms.

That being said, however, there is also hardly any substantial work on the Defence Intelligence Agency (DIA) in the United States beyond Scanlon's contribution. Much the same might be said not merely of the other Five Eyes intelligence allies but of the lion's share of other non-Anglophone systems with national agencies consuming more than just the lion's portion of scholarly interest. This includes the much-examined Soviet and Federal Russian systems where the Glaveniye Upravleniye Razvedivatelniye (GRU) has remained a rarely and even then idiosyncratically treated side-topic $^{11}$, almost as ignored as it is unreformed in the wake of the fall of the USSR. And so the academic neglect of defence intelligence as sphere of inquiry is not a peculiarly British malaise, but a malaise of the entire intelligence studies enterprise. As we shall see below, it is a neglect that reflects a long-running and wide-spread official neglect and mismanagement of a vital element of national security assets and capabilities.

\section{The Idea of Defence Intelligence}

Michael Warner famously warned intelligence scholars and practitioners alike that 'If you cannot define a term of art, then you need to rethink something ${ }^{12}$, echoing his $19^{\text {th }}$ century compatriot Charles Pierce's demand that philosophy serve to 'make one's meaning clear'. ${ }^{13}$ And so it is worth pausing a moment to clarify what exactly is meant by defence intelligence as distinct from national and other forms of intelligence. As noted above, the notion of military intelligence - more precisely armed forces intelligence since, at least in the UK, 'military' historically denoted strictly the Army and War Office - is well established and well understood. Military and naval intelligence branches date to the $19^{\text {th }}$ Century with air force intelligence components appear in short order after the $20^{\text {th }}$ century emergence of substantial and institutionalised air power. Defence intelligence entities are,

\footnotetext{
${ }^{7}$ Scanlon, Charles Francis. In Defense of the Nation: DIA at Forty Years. (Washington, DC: USGPO, 2001).

${ }^{8}$ Huw Dylan Defence Intelligence and the Cold War: Britain's Joint Intelligence Bureau 1945-1964 (Oxford: Oxford University Press, 2014).

${ }^{9}$ Philip H.J. Davies Intelligence and Government in Britain and the United States: a Comparative Approach (Santa Barbara CA: Praeger Security International, 2012) passim but Vol.2 in particular.

${ }^{10}$ Brian Jones Failing Intelligence: the True Story of How We Were Fooled into Going Into War in Iraq (London: Biteback Publishing, 2010).

${ }^{11}$ Leading accounts of post-Soviet intelligence restructuring such as Michael Waller's Secret Empire (Boulder Co: Westview Press, 1994) and Amy Knight's Spies without Cloaks: the KGB's Successors (Princeton: Princeton University Press, 1996) scarcely mention the GRU even though it alone emerged from the collapse of the USSR almost entirely unaltered, while the main Cold War vintage contributions on GRU by defector Vladimir Rezun writing as Viktor Suvorov can only charitably be described as merely 'idiosyncratic', see e.g. Soviet Military Intelligence (London: Hamish Hamilton, 1984) and Spetsnaz: the Story of the Soviet SAS (London: Grafton Books, 1989).

12 Michael Warner, "Wanted: A Definition of Intelligence," Studies in Intelligence Vol.46, no.3 (2002) p.15.

${ }^{13}$ Charles Peirce How to Make Our Ideas Clear," in Philosophical Writings of Pierce, ed. Justus Buchler (New York: Dover, 1955), p.25.
} 
however, of a more recent vintage with most organisations badged as such appearing during or after the 1960s.

Taking the British DIS and American DIA as points of departure, one sees two parallel and interconnected criteria for articulating the idea of defence intelligence. The first is the collaborative, in management theory language 'contributive' ${ }^{14}$, sharing of raw intelligence and analytical judgements at a tri- or quad-service (when one includes civilian defence officialdom) level. In the British case this developed to support tri-service joint planning in the 1930s under the auspices of the Chiefs of Staff apparatus that had taken shape in the second half of the $1920 \mathrm{~s}^{15}$, and in the United States to support an analogous need although that did not become compelling until well into the Second World War. ${ }^{16}$ We may think of this as the joint intelligence agenda. The second is the provision of intelligence support to unified and integrated tri-service leadership at the political, i.e. Cabinet, as well as command staff levels. It is the emergence of amalgamation of armed services under overarching Ministries and Departments of Defence, with Cabinet defence political portfolios, which really drives the emergence of defence building on earlier peer-group joint intelligence mechanisms.

Thus defence intelligence is perhaps most usefully thought of as quad-service intelligence production in support of defence as a corporate whole as embodied the official level in a multiservice command staff and unified defence political leadership. ${ }^{17}$ Seeing defence intelligence in these terms necessarily means identifying the function with strategic level of military doctrine, decision-making and policy. It also implies that the role of defence intelligence in the national intelligence community naturally supports and parallels the role of the defence Cabinet portfolio in the wider armature and conduct of national security. As will become apparent, however, these seemingly intuitive inferences present serious difficulties when putting defence intelligence and its associated agencies into practice.

\section{The Institution of Defence Intelligence}

Part of the problem for the UK is that when referring to Britain's defence intelligence one is not really talking about a single entity but a collective or confederal intelligence-community-in-miniature that evolved into its current intricate form after the end of the Cold War. Indeed, the multifarious nature of the defence intelligence function in the UK is one of the reasons for a series of puzzling rebrandings since the mid-1990s. At the turn of the previous decade Michael Herman noted with a hint of puzzlement the MoD's intelligence assessment hub being renamed Defence Intelligence

\footnotetext{
${ }^{14}$ The term is coined by Tom Burns and George Stalker in their T. Burns and G.M. Stalker, Management of Innovation (London: Tavistock, 1961), pp. 120-2.

${ }^{15}$ Interestingly, this development has been well-documented in the public domain at least since the second half of the 1950s, see F.M.G. Wilson The Organization of British Central Government 1914-1956 (London: George Allen \& Unwin Ltd. 1957) pp.297-298.

${ }^{16}$ Suggestive of the lack of regard to defence intelligence as much in the USA and UK, the definitive account of the wartime US Joint Intelligence Committee remains Larry Valero's 'The American Joint Intelligence Committee and Estimates of the Soviet Union, 1945-1947.' Studies in Intelligence unclassified edition, no. 9 (Summer 2009) pp.65-80.

${ }^{17}$ This definition parallels, at a lower institutional level of analysis, that I proposed in 2012 for a definition of national intelligence as intelligence support to the government as a corporate whole (rather than, more narrowly but traditionally), intelligence in support of national security. See PHJ Davies Intelligence and Government in Britain and the United States: a Comparative Approach Vol. 1 p.25.
} 
Assessment Staff (DIAS) from the long-standing and well-recognised DIS. ${ }^{18}$ This arose because after Front Line First the intelligence empire under the Chief of Defence Intelligence had been formally expanded to give him line management of an assortment of additional organisations that had previous stood as entirely separate agencies or formally separate agencies over which CDI had held tasking and a measure of supervisory authority at one remove in chain of command. ${ }^{19}$ As denoting CDI's organisation, Defence Intelligence Staff now stood for a wider apparatus within which the assessment enterprise was merely one amongst equals, and not even first. By 2010 it was felt that even this exercise in distancing had not been enough and the DIS 'brand' was still too identified with a coterie of tweedy analysts sequestered in the Old War Office Building (OWO) and the vague and ambiguous Defence Intelligence became the new collective identity for the CDI machine, a phrase that unhelpfully is now both generic and brand - with neither especially well understood outside the walls of MoD Main Building, OWO or the gleaming, new-fangled 'floorplate' of RAF Wyton.

In essence, today's Defence Intelligence is divided into two main divisions under CDI. The first and more established identity is DIAS, the institutional formally known as DIS under the Mountbatten Reforms. Headed by a civilian Deputy Chief of Defence Intelligence (D/CDI) at Director General (two star) level in current Civil Service grades ${ }^{20}$, this is the analytical arm of the agency staffed by a mix of armed service secondees and career civilians (many of whom are 'retreaded' retired service officials. In many respects, it has long being DIAS which has dominated the 'brand identity' of Defence Intelligence chiefly because the agency was (as will be examined in greater detail below) originally created to consolidate the collating and assessment work of the three Service Intelligence Branches and a somewhat experimental post-war quad-service assessment organisation, the Joint Intelligence Bureau.

Michael Herman has provided a telling generic character sketch of the DIS 'civilian':

Picture a retired service officer aged fifty-five. As a younger man he had a good average service career, but a posting to intelligence was a self-confirming indication that he was not destined for the top prizes. But he liked the work, took his pension at forty-five and continued the work as a civilian ... He is a conscientious man and comfortable in a tight hierarchy in which he and his colleagues do the detailed analysis while those higher up the line draw on it for broad pictures ... he is a modest man who does not claim to be a deep thinker about Soviet intentions and strategy. He enjoys getting the detailed analysis right and is respected for his expertise ... Intelligence depends greatly on him, and for what he gives he is a bargain ... But he fits into a service organisation not inclined to challenge military orthodoxy. ${ }^{21}$

A younger generation of professional, career analyst has become a more prominent feature of the DIAS cohort since the 1990s, deep thinkers as much on analytic methodology as strategic and

\footnotetext{
${ }_{18}$ Michael Herman Intelligence Services in the Information Age (London: Frank Cass, 2001) p.68.

${ }^{19} \mathrm{PHJ}$ Davies Intelligence and Government in Britain and the United States Vol.2 p.253.

${ }^{20}$ In Civil Service 'old money' Director equates to Deputy Undersecretary of State (DUS); in today's seniority currency the equivalencies are Permanent Secretary (unchanged) $=4 / 5^{*}$; Director General $=$ Deputy Secretary $($ DUS $)=3 * ;$ Director $=$ Undersecretary $(A U S)=2 *$; Deputy Director $=$ Assistant Secretary $=1 * ;$ see,e.g. http://www.civilservant.org.uk/information-the_armed_services.html (accessed 30/10/2015).

${ }^{21}$ Herman Intelligence Power in Peace and War (Cambridge: Cambridge University Press, 1996) pp.249-250; the sketch in question is originally from an unpublished lecture in 1990.
} 
defence issues ${ }^{22}$, but retired service personnel (as likely to be female as male, unlike Herman's slightly dated sketch) have remained the mainstay of DIAS. . Nonetheless, it is not hard to see how the DIAS desk officer stereotype could easily be seen as constrictive not merely by an evolving analytical profession but by the senior leadership of an organisation increasingly involved in increasingly high-technology intelligence collection and processing.

The other main branch of DI is a very different entity, and it is arguably that part of the agency least well served by Herman's portrant. After the consolidation of CDI's 'empire' most of the intelligence collection components were gathered together under a Director General Intelligence and Geographic Resources. This branch was reconstituted in 2005/6 as an Intelligence Collection Group, headed by a one star serving officer. ${ }^{23}$ However, after the restructuring of the MoD's higher management under Lord Levene's 2011 review of MoD organisation ${ }^{24}$ it was rebranded the Joint Force Intelligence Group (JFIG) to dovetail it into the establishment of Levene's proposed Joint Force Command (JFC). Headquartered at the Pathfinder facility at RAF Wyton, JFIG overseas a range of specialist collection and processing units such as the Defence Intelligence Fusion Centre (formerly the Defence Geospatial Intelligence Fusion Centre, DGIFC, [2013-2015], formerly the Joint Air Reconnaissance Intelligence Centre, JARIC, [1947-2013]); the Defence Geographic Centre, DGC, (formerly the Military Survey); the Joint Service Signals Organisation (JSSO, a resuscitated version of the Cold War Composite Signals Organisation ${ }^{25}$ ) and a geospatial Engineers unit designation with the Joint Aeronautic and Geospatial Organisation or JAGO. The lion's share of DI's manpower sits in JFIG, which is not surprising. JARIC historically has been roughly the same size as DIAS while Military Survey/DGC numbers more than half again more than both DIAS and JARIC combined. ${ }^{26}$ There is generally less transparency surrounding defence intelligence matters in the UK than the national agencies, and so few specifics are available on the manpower of JSSO and JAGO, but all told JFIG is several times the size of its analytical counterpart. Alongside DIAS and JFIG under CDI is the Defence Intelligence and Security Centre (DISC) which includes the Defence College of Intelligence and the headquarters of the Army's Intelligence Corps.

\section{Problems with and of Defence Intelligence}

Some two decades ago, Michael Herman went to some pains to point out the fact that defence intelligence represented a different class of problems from those conventionally identified as issues

\footnotetext{
22 PHJ Davies Intelligence and Government in Britain and the United States Vol.2 p.253, 'Defence Intelligence in the UK After the Mountbatten Reforms: Organisational and Inter-Organisational Dilemmas of Joint Military Intelligence' Public Policy and Administration Vol.28 No.2 (April 2013) p.208; Nick Hare and Paul Collinson 'Organisational Culture and Intelligence Analysis: A Perspective from Senior Managers in the Defence Intelligence Assessments Staff' Public Policy and Administration Vol.28 No.2 (April 2013) p.219.

${ }^{23}$ Philip H.J. Davies 'Defence Intelligence in the UK after the Mountbatten Reforms' p. 206.

${ }^{24}$ Lord Levene of Portsoken Defence Reform: an Independent Report into the Structure and Management of the Ministry of Defence (London: TSO, 2011).

25 The CSO was the Cold War successor to the joint-service intercept Y Organisation that was originally set up in the 1920s. See e.g. Richard Norton-Taylor and Hugh Lanning A Conflict of Loyalties: GCHQ 1980-1991 (Cheltenham: New Clarion, 1991), Michael Herman Intelligence Services in the Information Age pp.180-190; Davies Intelligence and Government in Britain and the United States vol.2 pp.20, 85-86; 131.

${ }^{26}$ Ministry of Defence 'Memorandum from the Ministry of Defence: JARIC and Military Survey and Their Proposed Merger' appended to House of Commons Select Committee on Defence Fourteenth Special Report HC930 (London: HMSO, 2000).
} 
in intelligence conceptualisation and practice. ${ }^{27}$ Defence intelligence was not merely a specific subset of the classic problems but dogged by unique challenges arising from its position in government. Herman's diagnosis of the 'problems of defence intelligence' was, however, one shaped by the experiences and legacies of the Cold War encapsulated barely a half decade after that global nuclear stand-off had drawn to its close. The most fundamental difficulty for defence intelligence, he argued, was that such institutions were subject to an intrinsic conflict of inflict arising from the fast that their institutional and political masters were the likely beneficiaries (or otherwise) of their intelligencers might reach. Herman suggests something of a perfect storm in which the difficulties of acquiring information on military and strategic systems enshrouded by an adversary's denial and deception measure created a miasma of uncertainty in which a militaryinstitutional inclination towards worst-case appreciations, pressure not to undermine considerable 'Western political capital invested in the Soviet threat' - not to mention comparable financial capital likewise invested - converged with an ethos where 'on the whole, it is more satisfying, safer professionally and easier to live with oneself and one's colleagues as a military hawk than as a wimp ${ }^{28}$ and the absence of a permanent, career cohort of professional analysts comparable to the national intelligence community. The result was a problematic mix of under- and overestimates of Soviet strength in which the former, once discovered, provided added impetus to the latter.

Such hazards of linked under- and over-estimation have continued to afflict defence intelligence, of course, as inquiries on both sides of the Atlantic concerning erroneous assessments of Iraqi nonconventional weapon (and especially nuclear) development programmes prior to 2003 have clearly indicated. ${ }^{29}$ But to a very real degree the deepest problems associated with defence intelligence are of a different order and more fundamental than those highlighted by Herman. Former DIAS analyst Brian Jones has reflected pointedly on the relationship between Defence Intelligence and central coordination through the Joint Intelligence Committee, a reflection coloured precisely by the chastening experience of the Iraq war. In his view, the Cabinet Office intelligence machinery 'Exists to coordinate the community and to ensure that assessments are independent of motives and pressure which may distort judgements ... independent of the vested interests of those who collect intelligence and are likely to be biased in favour of their own inputs, and of those who might be biased to interpret the intelligence to match their own policies or prejudices.' However, on technical and scientific matters, the JIC's Assessments Staff rarely had relevant specialist know-how in-house, consequently 'As the major repository of all-source intelligence and career intelligence analysts and specialists, the DIS was often the only knowledgeable and experienced contributor to the process. Thus the laudable concept of unbiased assessment was undermined' ${ }^{30}$

That being said, in recent years a range of no less fundamental and persistent problems have shown themselves as being even more formative to the development and current state of affairs in UK defence intelligence. The principle such problems are those of the divided mandate which dogs most defence intelligence institutions regardless of nation or government, the economic problem of fixed sum resourcing, an endemic challenge to public expenditure but one intensified by DI's divided

\footnotetext{
${ }^{27}$ Herman Intelligence Power pp.240-256

${ }^{28}$ Herman Intelligence Power p.247.

${ }^{29} \mathrm{See}$, in particular, Lord Butler of Brockwell Review of Intelligence on Weapons of Mass Destruction (London: TSO, 2004) and The Commission on the Intelligence Capabilities of the United States Regarding Weapons of Mass Destruction Report to the President (Washington DC: United States Government Printing Office, 2005).

${ }^{30}$ Brian Jones Failing Intelligence p.7.
} 
mandate, and the problem of locating any defence intelligence entity simultaneously both beside and above single-Service intelligence functions within the defence institutional hierarchy.

\section{Divided Mandate}

The first truly pervasive problem of defence intelligence is that it is operationally and institutionally neither here nor there, so to speak. It serves both Departmental and national requirements, priorities and political masters but operates under the enforceable line management of only the former and in some respects as least amongst equals when dealing with the latter. DI is represented on the UK's Joint Intelligence Committee by the Chief of Defence Intelligence alongside the national agencies and their heads but as a slightly junior Departmental voice at three star or, in Civil Service 'old money' terms Deputy Undersecretary, today's Director General grade. By contrast, the security and intelligence agency (SIA) heads and JIC Chair all hold Permanent Secretary status. Even this level of seniority was recently placed in question by Lord Levin's review of defence management in the UK where it was suggested that the Chief of Defence Intelligence be demoted to two-star level. ${ }^{31}$

At the same time, defence intelligence activities and institutions sit a level above the operational intelligence coalface where the greater part of military intelligence work and its impact have taken place over the course of a generation dominated by expeditionary and counter-insurgency operations. In 2015 the defence intelligence function is removed a step from the boom industry of military 'intelligence, surveillance and reconnaissance' (ISR) which has dominated so much of defence intelligence work, acquisition and development. And while under a series of activist Directors the DIA has managed to leverage its centrality within the DoD and concentration of analytical and technical competencies to secure a more secure role within the US intelligence and defence communities ${ }^{32}$, the UK the function and institution alike seem ever more precariously balanced with future prospects characterised by decreased clarity and confidence even though investment elsewhere in the intelligence enterprise has been steadily increasing for two decades.

It is important to stress that the fraught balance between the competing priorities of defence and national intelligence is not merely the consequence of national requirements been laid upon defence intelligence as a post-hoc or opportunistic use of assets and capabilities just because they are there. The central role of defence in wider national security means that the defence intelligence has a comparably central role to play in the production of national security intelligence. In this sense, the tension is intrinsic to the defence role. At the same time, diseconomies ${ }^{33}$ of scale in highly specialised and expensive - usually technical -- intelligence collection systems that are often most usefully located in the defence architecture (overhead reconnaissance being foremost such example) but generate product of national (or non-defence departmental) significance also means that such dual-use capabilities have to serve both uses to justify the expenditure. To a certain degree, locating a particular system in the defence rather than, say, foreign affairs portfolio is more

\footnotetext{
${ }^{31}$ Levene Defence Reform p.27.

32 For D/DIA Ed Soyster's and his principal successor James Clapper's successes in leveraging their agency's position within the DoD see Scanlon In Defence of the Nation pp.195-211, also Davies Intelligence and Government in Britain and the United States Vol12 pp.150, 308-311.

${ }^{33}$ By which I mean systems that would be prohibitively expensive to duplicate in different departments. Imagine, for example, the cost implications of creating parallel reconnaissance satellite programmes for political and military operational purposes in contrast with those of creating multiple centres for the recruitment and handling of covert human sources.
} 
a question of accounting and line management (or political) nicety than inherent necessity. Thus defence, and hence defence intelligence, have unavoidable national responsibilities that lie in some competition with defence-only interests. On the one hand this creates a divided mandate, competing priorities and fraught lines of responsibility. On the other, this creates serious resource management problems.

\section{Fixed Sum Resourcing}

While the resource management problems of defence intelligence arise from the same overall intrinsic tensions as those of the divided mandate, they occur at a different level of analysis and in ways that, more often than not, serve to intensify the problems of the divided mandate. Over the decades, a commonly given defence for locating a range national intelligence capabilities and functions in the US Department of Defence is that they should be less vulnerable to budget cuts as smaller parts of a bigger budget than as small, visible, and vulnerable budget lines in their own right. While the jury might still be out on this in the United States, British experience shows clearly and depressingly that this argument absolute does not apply to Whitehall. What British experience shows is that, in the difficult process of carving the (often shrinking) defence fiscal pie, intelligence is almost guaranteed to be first in line for financial predation against more concrete combat and combat support assets and investments, regardless of the scale or significance of national requirements and priorities that underpin DI's significance in the larger machinery of government and bigger political picture.

In 2011 Lord Levene noted that intelligence does not stand as a Top-Line Budget (TLB) in its own right within the MoD budget but is a line-item within the Central TLB where it 'sits uncomfortably ... in the absence of a natural home.' ${ }^{34}$ This also means that intelligence is vulnerable to discretionary alterations to its resourcing levels by senior MoD management than would be less the case were it enshrined as a TLB. The steady scaling back of DIAS since the end of the Cold War has widely been reported and frequently decried. DIAS came out of that conflict with an approximate strength of 800 , only to be pared by in the latter half of that decade to $600 .{ }^{35}$ By 2008 this had dwindled even further to $450 .{ }^{36}$ Despite being one of the only intelligence agencies to emerge from Iraq with its reputation intact after the 2004 Butler review ${ }^{37}$, in the midst of the post-2006 Taliban resurgence in Afghanistan and the run up to the 2009 'surge' in that theatre, DIAS saw its numbers due to be reduced a further $20 \%{ }^{38}$ It was thus reduced in manpower (to little more than 400 ) and in morale ${ }^{39}$ that DIAS came into the current decade to be confronted with the so-called Arab Spring, remobilisation of ISTAR and logistical elements to support the French in Mali and the Central African Republic, and during the last two year resurgent Russian aggression in the Crimea and eastern Ukraine.

Less visible was the whittling down of geospatial (GEOINT) and imagery intelligence (IMINT) capabilities during much the same period. The status of IMINT and GEOINT has been a fraught one

\footnotetext{
${ }^{34}$ Levene Defence Reform p.45.

${ }^{35}$ Herman Intelligence Services in the Information Age p.71; Michael Smith New Cloak, Old Dagger pp.202-204.

${ }^{36}$ Intelligence and Security Committee Annual Report 2007-2008 (London: TSO, 2008) p.41.

${ }^{37}$ Butler Review of Intelligence on Weapons of Mass Destruction passim.

38 Intelligence and Security Committee Annual Report 2007-2008 p.42.

${ }^{39}$ Hare and Collinson 'Organisational Culture and Intelligence Analysis' p.223.
} 
for decades ${ }^{40}$ and a recurrent point of complaint by successive Intelligence and Security Committees who have consistently argued for greater autonomy or even national status for the function. ${ }^{41}$ Between April 2000 and June 2006, the MoD experimented with an amalgamated imagery and mapping organisation analogous in some respects to the US National Geospatial Intelligence Agency (NGIA). Headed at one-star level by an Air Commodore, the Defence Geographic \& [sic] Imagery Intelligence Agency (DGIIA; later the Defence Geospatial Intelligence Agency or DGIA) essentially created an additional layer of management on top of JARIC and DGC. From 2002 to 2005 the operating costs of DGIIA were reduced steadily from $f 144,766$ in 2002-3 to $f 141,902$ in 2003-4 and in 2004-5 to $f 130,430 .{ }^{42}$ Slightly bizarrely, this decline covered not only the intensified level of activity immediately after September 11, 2001 and the early stages of Operation HERRICK in Afghanistan but also the British contribution to the 2003 invasion of Iraq, Operation TELIC. Indeed, 2003-4 saw some (albeit limited) increased in spending on 'operating activities' of $£ 3,191$ over the TELIC period - even though overall spending was being reduced by only slightly less $(f 2,874)$ - only to have that expenditure drop to below 2002 levels the following year. ${ }^{43}$ Only slightly less striking than the pattern of reduction during a period of much heightened military operational activity and generally raised threat levels is the very small sums covered by the entire imagery and mapping enterprise and their fluctuations.

The essential point to be gleaned from these indicators is that intelligence spending where controlled by the MoD consistently takes a low priority in Departmental financial priorities as compared with other combat operational spending priorities - even during times of conflict or crisis. By comparison, the SIA increased from around $£ 940$ million to $£ 1,126$ million during the same period. ${ }^{44}$ Driven by the particular tooth-to-tail spending priorities of the armed forces, intelligence resourcing as actually far more vulnerable within a Departmental budget than national intelligence has been as a high-profile, stand-alone budget line.

\section{Institutional Hierarchy}

A troubled question on both sides of the Atlantic has been the relationship between defence intelligence agencies and the various single-service intelligence branches of the armed forces. Both DIS and DIA were established with a similar organisational aim, but driven by very different considerations and contexts that are almost archetypical of the evolution of the two intelligence communities. In both cases, the proposed defence intelligence organisation was intended to take the shape of a hostile take-over of armed forces intelligence from the corporate centre of defence, a merger that would have seen the independent headquarters of the service intelligence branches dismantled and the those branches abolished as separate agencies. In the US, Secretary of Defence Robert McNamara was motivated to abolish the separate service intelligence agencies in order to mitigate or do away with the Zegartesque intelligence cacophony of competing service views and

\footnotetext{
${ }^{40}$ For an overview see PHJ Davies 'Imagery in the UK: Britain's Troubled Imagery Intelligence Architecture' Review of International Studies (2009) Vol.35 pp.957-969.

${ }^{41}$ See e.g. Intelligence and Security Committee Annual Report 1999-2000 (London: TSO, 2000) pp.11-12, Annual Report 2001-2002 (London: TSO, 2002) pp.13-14, Annual Report 2003-2004 (London TSO 2004) p.36.

${ }^{42}$ Defence Geographic \& Imagery Intelligence Agency Annual Report and Accounts 2003-2004 HC840 (London: TSO 2004) p.22, Annual Report and Accounts 2004-2005 HC271 (London: TSO, 2005) p.26.

${ }^{43}$ DGIIA Annual Report and Accounts 2003-2004 p.24, Annual Report and Accounts 2004-2005 p.28.

44 See Intelligence and Security Committee Annual Reports for the same period (London: TSO, 1999, 2001. 2003, 2004, 2005, 2006).
} 
interests with which he found himself confronted on taking office. ${ }^{45}$ By contrast, in the UK, amalgamating the service intelligence branches was seen primarily as a cost-saving measure, in parts by reducing executive and senior working-level salaries and overheads, doing away with parallel administrative architectures and finally identifying and eliminating any redundant activities across the three service intelligence branches and the post-war, quad-service Joint Intelligence Bureau. ${ }^{46}$ In the United States that hostile take-over was an almost complete failure leaving DIA and its Director all but surplus to requirements - except as a stalking horse for DoD institutional rivalries with the civilian intelligence agencies like the Department of State's Bureau of Intelligence and Research and (especially keenly) the Central Intelligence Agency -- until the cusp of the 1990s. In the UK, however, the effort was only too successful with Britain really only awakening to the unintended consequences of that putative success a decade and a half after the end of the Cold War.

Both Peter Davies ${ }^{47}$ (a contributor to this volume) and myself ${ }^{48}$ have, separately and elsewhere examined how British plans to amalgamate the individual Service intelligence branches (SIBs) into the Defence Intelligence Staff took place, and how for an interval DIS simply entailed placing the SIBS under a common MoD line management with JIB. This did not last long, and under an organizational doctrine called 'functionalization' the top managements of the three SIBS and their staff organisations were abolished and the single-serve geographical and functional sections amalgamated under a Directorate of Service Intelligence (DS Int). The theory was that Service DS Int representatives would produce the single-service appreciations for their respective chiefs of staff that the defunct SIBs had existed to provide with the advantage of being able to draw jointly on the resources and views of collocated colleagues from the other Services and former JIB.

It is important to keep in mind, however, that the focus of DIS was intelligence support at a joint level to the Chiefs of Staff Committee (COS) and to Ministers, essentially as a strategic asset. And so while the DS Int sections existed in principle to provide continuity of single-service intelligence support, as a whole DIS and its senior management were beholden to central defence requirements, such as those articulated from the 1980s under the NATO Collection Coordination and Requirements Management (CCIRM) process. ${ }^{49}$ Unsurprisingly, this applied a competing pressure upon the single Service responsibilities of the DS Int sections which reduced the relative importance of both strategic and operational intelligence support in their workflows. Over the subsequent decade, the doctrine of withdrawal from 'East of Suez' dismantled the most of the UK's deployed defence and joint military operational intelligence arrangements such as the Joint Intelligence Committee (Far East), Joint Intelligence Bureau (Far East) and Joint Air Reconnaissance (Far East) based at Phoenix Park in Singapore and, closer to home (and technically west of Suez), a scaling down of their counterparts in Cyprus such as JARIC (Near East) and the Middle East version of the JIB.

\footnotetext{
${ }^{45}$ Davies Intelligence and Government in Britain and the United States Vol.1 pp.149-150; 235-236.

${ }^{46}$ Pete Davies 'Estimating Soviet Power: The Creation of Britain's Defence Intelligence Staff 1960-1964' Intelligence and National Security Vol.26 No.6 (December 2011) pp.818-841; Philip H.J. Davies Intelligence and Government in Britain and the United States Vol.2 pp.182-186; 'Defence Intelligence in the UK After the Mountbatten Reforms' pp.201-203.

${ }^{47}$ Peter Davies 'Estimating Soviet Power' pp.837-840 (Davies notes, however, that at least for one Cabinet Minister there was much the same suspicion of Service self-serving bias as that held by Robert McNamara in the USA).

$48 \mathrm{PHJ}$ Davies Intelligence and Government in Britain and the United States Vol.2 pp.185-185.

${ }^{49}$ Herman Intelligence Services in the Information Age pp.84, 195; Davies Intelligence and Government in Britain and the United States Vol.2 pp.234-235.
} 
Consequently, just as the headquarters service intelligence functions were reducing their engagement in potential theatre- or campaign-level intelligence support to operational commanders the permanent, deployed operational intelligence architectures were also being dismantled.

As I have argued in greater detail elsewhere ${ }^{50}$, by the end of the 1970s, only the British Army retained a permanent, career-path intelligence trade in its Intelligence Corps and even that was seen in the first instance as tactical in the first instance and then operational in its work for elements such as the British Army on the Rhine (BAOR). ${ }^{51}$ With the loss of ACAS(I) and DNI neither the Royal Air Force nor the Navy had either a standing single-service operational intelligence function or an intelligence trade. With the Army seen as colonising the lion's share of joint intelligence appointments simply because of its available pool of Int Corps professional intelligence practitioners $^{52}$, and the sobering lessons of the intelligence demands of the First Gulf War, the Royal Air Force set about re-establishing a single-service Air Intelligence Centre at its Air Warfare Centre at RAF Waddington. It took the embarrassing political fall-out of an Iranian Revolutionary Guard Corps small-boat swarming attack on a boarding party from HMS Cornwall in March 2007 to give urgency and impetus to a previously moribund 2005 initiative to re-establish a Naval Intelligence or N2 function within the Navy.

The result has been establishment of a suite of single-Service intelligence fusion centres (the Air Warfare Intelligence Centre, Land Intelligence Fusion Centre and Maritime Intelligence Fusion Centre) alongside a central, strategic joint defence intelligence apparatus (DI in general and DIAS in particular). There is a degree to which, in the second decade of the $21^{\text {st }}$ Century, it seems that the UK has returned to a version of the status quo ante prior to 1963. If this is the case, however, this reflect less a failure of the central DI apparatus as such than the unintended consequences not merely of creating a central defence but also abolishing separate SIBs in the process. And for all the degrees to which the US DIA can be said to have fallen short of its original promise of a coordinated and coherent defence and military intelligence enterprise (until Soyster's term as D/DIA), at least the US avoided decapitating its own permanent operational intelligence capabilities. In the UK, it appears, the one joint intelligence relationship that remains to be firmly worked out and bedded in is that between central and single-service intelligence functions within the MoD.

\section{The Problem of Indifference}

A persistent issue throughout the evolution of Defence Intelligence in Britain has been the lack of independent scrutiny. Ironically, the supposedly secretive national agencies have had clear and more robust regulatory, oversight and accountability frameworks from the old 1985 Interception of Communications Act to the 1994 Intelligence Services Act than have ever been applied to military and defence intelligence elements. To be sure, over a decade the Intelligence and Security Committee (ISC) managed to extend its remit informally to cover defence intelligence as well as the

\footnotetext{
${ }^{50} \mathrm{PHJ}$ Davies 'Defence Intelligence in the UK after the Mountbatten Reforms' pp.208-209.

${ }^{51}$ Like much on the military intelligence front after the Second World War, the Intelligence Corps is woefully underexamined. For one of the few, dated and imperfectly informed attempts to articulate the role of the 'Int Corps' see e.g. Peter Gudgin MI? Military Intelligence: the British Story (London: Arms and Armour Press, 1989) pp.83-86 and historically Jock Hasswell British Military Intelligence (London: Wiedenfeld and Nicholson, 1973). 52 Private information.
} 
central intelligence machinery in Cabinet Office ${ }^{53}$, a reach only formally placed on a statutory footing under the 2013 Justice and Security Act. ${ }^{54}$ But the ISC's original remit was purely concerned with the national agencies alone. ${ }^{55}$ To a limited degree, some of the slack has been taken up by other Parliamentary committees. The most visible such case in the late 1990s was the House of Commons Public Accounts Committee's damning report on the stillborn, $£ 41$ million TRAWLERMAN computer system intended for DIS. ${ }^{56}$ In terms of on-going oversight and transparency, however, much of the most significant discussion of defence and military intelligence matters has been provided by the House of Commons Select Committee on Defence. This body has produced a number of reports on defence intelligence and ISTAR concerns over the last two decades. ${ }^{57}$ However these have received significantly less attention that the reports produced by the ISC even though they touch on areas of comparable security sensitivity and strategic significance (such as the IMINT special relationship with the USA or JARIC performance during specific campaigns such as Kosovo). ${ }^{58}$ It is hard to imagine either the CIA's analytical Directorate of Intelligence, IDAS's natural counterpart, or the National Geospatial Intelligence Agency, analogous to JARIC/DIFC, being so asphyxiated by persistent and pervasive public and political indifference.

The problem of scrutiny and lustration for DI is not the hoary old image of rogue elephants rampaging off the political reservation but the less dramatic but more practical and common one of value for money. ${ }^{59}$ If an organisation or function is insufficiently resourced, that can reach a level where even that investment made is insufficient to meet even the minimum requirements laid upon it because it below a minimum working threshold. ${ }^{60}$ At that point, even that bare-bones investment becomes a wasted expenditure because the benefits yielded no longer justify that money or manpower. As we have seen, the ISC has repeatedly warned that DI is not resourced sufficiently to

\footnotetext{
${ }^{53}$ Anthony Glees, Philip H.J. Davies and John N.L. Morrison, The Open Side of Secrecy: Britain's Intelligence and Security Committee (London: Social Affairs Unit, 2006) pp.40-42.

${ }^{54}$ The 2013 Act made a substantial number of changes of varying significance to the ISC, in particular Part One Sections 1 and 2 and Schedule 1.

55 See 1994 ISA Section 10.

${ }^{56}$ House of Commons Public Accounts Select Committee 18 ${ }^{\text {th }}$ Report 1997-1998: Ministry of Defence: Project TRAWLERMAN (London: HMSO, 1998) which reported, inter alia, that after cancellation in 1996 as not fit for purpose at a cost of $£ 41$ the MoD subsequently acquired a replacement system the following year for $£ 6$ million.

${ }^{57}$ See, e.g. House of Commons Select Committee on Defence, Seventh Report 1994-1995: Reconnaissance, Intelligence, Surveillance and Target Acquisition. (London: HMSO, 1995, HC 319), Fifth Report 1999-2000: The Defence Geographic and Imagery Intelligence Agency, HC 100 (London: TSO 2000); Fourteenth Special Report Session 1999-2000 (London: TSO, 2000); Thirteenth Report 2007-2008: The Contribution of UAVs to ISTAR, Eighth Report of Session 2009-2010: The Contribution of ISTAR to Operations, HC225 (London: TSO, 2010). ${ }^{58}$ Notably, like detailed SIA figures in ISC reports, detailed items referencing UK access to TALENT-KEYHOLE materials are at least partially redacted in the published reports, although this clearly indicates the sensitivity of the materials on which Defence Committee members are briefed. See, e.g. witness evidence for Fifth Report 1999-2000: the Defence Geographic and Imagery Intelligence Agency published on the Committee's webpage at http://www.parliament.the-stationeryoffice.co.uk/pa/cm199900/cmselect/cmdfence/928/92802.htm (accessed 19 November 2006).

${ }^{59} \mathrm{~A}$ recurrent theme in discussions of UK intelligence oversight has been the question of value for money and its greater practical significance than propriety in the conduct of the UK's agencies, the quintessential expression of which is Kenneth G. Robertson 'Accountable Intelligence: the British Experience' Conflict Quarterly Vol.8 No.1 (1988) pp.3-28, a notion captured in practice in the ISC's original mandate to examine the 'expenditure, administration and policy' of the national agencies in the 1994 ISA, Section 10(1).

${ }^{60}$ For an illustration of this problem through the application of Garrett Hardin's Tragedy of the Commons, see PHJ Davies MI6 and the Machinery of Spying (London: Frank Cass, 2004) p.342.
} 
meet its combination of national and Departmental requirements - let alone operational intelligence demands in-theatre - and the Commons Defence Committee has challenged the relative investment in analysis and exploitation as against collection. But these moments of lustration have historically been relegated on the fringes of these committees' interests. Even after changes under the 2013 Act, public furores such as domestic Jihadi violence and the Edward Snowden allegations have absorbed most public attention and the scarce investigatory resources of both standing and ad hoc oversight bodies. ${ }^{61}$ At the same time, the formal expansion of the ISC's remit under the 2013 leaves a possible question mark over whether the Commons Defence Committee will see any point in producing future reports on ISR/ISTAR and defence intelligence. This suggests a risk that defence and military intelligence are more rather than less likely to fall into the gaps between the various oversight processes of today's putatively more transparent British government.

\section{Prospects and Implications}

Both the divided mandate and resource allocation issues have been principle points of discussion when DI has received attention from commentators and official reviews alike. As has been noted, the Intelligence and Security Committee has raised these issues with dogged regularity, and even repeatedly raised the possibility of cross-subsidising work conducted in support of national requirements and priorities from the Single Intelligence Account. Although this proposal would both take a substantial volume of DI work off the defence spending account while also firewalling national work from the fixed-sum spending pressures that affect the MoD it has consistently achieved little or no traction. It has been suggested in some quarters that there is a concern amongst the national agencies that this would involve taking SIA funds away from the agencies thereby weakening investment in those organisations. ${ }^{62}$ This suggestion has, however, little credibility. Cross-subsidy proposals have never been about reallocating money away from the agencies but about taking funds already directed towards intelligence in the MoD's Central TLB and managing them through the SIA instead. It is hard, therefore, to see why cross-subsidy suggestions have fallen on such stony ground, unless Defence officials are simply resistant to seeing any MoD funds redirected elsewhere perhaps even, in the bleakest scenario, precisely so that DI-earmarked moneys provide a nest egg that can be raided for other needs as and when.

The institutional hierarchy problem is still in flux, and the future of DIAS deeply in doubt. As noted, the three armed service components have effectively had to re-established service intelligence branches under the guise of the buzzword-friendly rebranding of 'fusion centres'. Less obvious is the impact on DIAS. Rather than returning to a revivified Kenneth Strong JIB formula, DIAS appears increasingly balkanised with the all-source task evolving into a distributed rather than concentrated function. While a sizeable portion of DIAS still sits in the OWO, that component of the organisatoin has been under pressure to relocate for some time while MoD finance managers seek to realise the

\footnotetext{
${ }^{61}$ Consider that the Snowden furores have already triggered a formal Statement (ISC 'Statement on GCHQ's Alleged Interception of Communications Under the US PRISM Programme' (London: ISC, 2013)), and contributed to the production of two substantial reports by the ISC (Access to Communications Data by the Intelligence and Security Services (London: TSO, 2013) and Privacy and Security: a Modern Legal Framework (London: TSO, 2015), and an independent review by David Anderson QC A Question of Trust: Report of the Investigatory Powers Review (London: Williams Lea Group, 2015) , during much the same interval that the ISC was also producing its even more detailed report on the killing of Lee Rigby, ISC Report on Intelligence Relating to the Murder of Fusilier Lee Rigby (London: TSO, 2014).

${ }^{62}$ Private information.
} 
real estate value of the central London real estate upon which it resides. More crucially, one part has moved into the MoD Main Building to provide operational intelligence support to the Chiefs of Staff, another has moved to Joint Force Headquarters at Northwood and still another portion is being relocated to join the Pathfinder enterprise at RAF Wyton. In this setting, these DIAS elements fall under some very diverse dual-control line management between D/CDI as head of DIAS on the one hand, and the headquarters authority of the Defence Staff in London, CO of JFC in Northwood and Commander, Joint Force Intelligence Group at Wyton respectively. Apart from acting as a shop steward for the all-source profession, it is increasingly hard to see what real authority $D / C D I$ can wield over the work and conditions of the further flung parts of his organisation.

In fact, if one looks at the recent evolution of all-source analysis as a taught skill set of principles and analytical techniques (structured or otherwise), the work of DIAS looks less and less like the kind of thing that needs its own organisational silo and more like a suite of supplementary skills that can be incorporated into the skill-sets of more technologically and professionally distinct intelligence disciplines and organisations. The future for defence intelligence assessment appears less of institutional reform or adaptation than a more fundamental transformation into a fluid and constantly shifting network of analytic cells, project teams and task forces. D/CDI might survive as a sort of 'head of profession', but it seems increasingly unlikely that DIAS, or an equivalent, as such will continue to exist within a decade or so. The more plausible scenario is an almost transient, peripatetic community of all-source practitioners liable to re-tasking and relocation around Whitehall, mainland UK headquarters and deployed commands bound together not by a common line management but common training and methods inculcated by programmes like the Defence Intelligence Assessment Course at the Defence Intelligence and Security Centre (DISC) at Chicksands.

It is more than ironic that less secrecy surrounds the Secret Intelligence Service than Defence Intelligence, that SIS should be more a household name as MI6 than any actual military or defence intelligence element. Like so many of the failures to deal with the difficulties and dilemmas of defence intelligence in the United Kingdom, it is a tragedy and one played out over decades where the cost in blood and treasure has been largely overlooked or ignored by the public, press and politicians alike. But there are reasons to believe that this is not peculiar to the British experience. As has also been noted above, counterpart issues and concerns are readily discerned when setting the UK's experience against that of the USA, and it would seem likely therefore that these problems are likely to be more widespread. A major consideration is the degree to which defence ministries encompass their own proprietary intelligence communities composed of various single-service, jointservice and defence intelligence components. How these sub-communities, almost in the sociological sense intelligence subcultures ${ }^{63}$, and perhaps other departmental intelligence subcultures, relate within themselves as well as to the central, national intelligence apparatus remains an area that warrant far deeper investigation globally, not just in the Anglosphere and amongst its allies. It is also evident that close examination of defence intelligence institutions casts the so-called 'intelligence community', both in terms of national intelligence institutions and as an interagency enterprise across government, as a corporate whole in a very different (and often less flattering) light than studies focused exclusively at the national level. The study of defence intelligence therefore has the potential the play the role of what Talcott Parsons has referred to as a

\footnotetext{
${ }^{63} \mathrm{~A}$ classic study in the sociological tradition of studying subculture is Dick Hebdige Subculture: the Meaning of Style (London: Methuen, 1979).
} 
'residual category' ${ }^{64}$ or Thomas Kuhn's notion as an 'anomaly' ${ }^{65}$, that is, a problem on the flanks of a subject that has the potential to transform our basic understanding of that subject once it is thoroughly investigated.

64 Talcott Parsons The Structure of Social Action (New York: The Free Press, [1937] 1968) pp.17-20 and passim.

65 Thomas Kuhn The Structure of Scientific Revolutions $2^{\text {nd }}$ Revised Edition (Chicago: University of Chicago Press, 1970). 